\title{
Recombinant Super-compound Interferon
}

National Cancer Institute

\section{Source}

National Cancer Institute. Recombinant Super-compound Interferon. NCI Thesaurus.

Code C121542.

A recombinant form of the naturally-occurring cytokine interferon-alpha (IFN-a) that has

a modified spatial configuration, with immunomodulating, antiviral and antineoplastic activities. Upon administration of recombinant super-compound interferon (rSIFN-co), this agent binds to IFN-specific cell surface receptors, resulting in the transcription and translation of genes whose protein products have antiviral, antiproliferative, anticancer, and immune-modulating effects. The 3-dimensional conformational change improves efficacy and causes less side effects compared to IFN-a. 